\title{
DiALECTIC AND \\ Its Place in the \\ DeVELOPMENT OF \\ Medieval Logic
}

Eleonore Stump

Cornell University Press

ITHACA AND LONDON 
Dialectic and

Its Place IN THE

DeVElopment OF

Medieval Logic 
TRANSLATED AND ANNOTATED BY ELEONORE STUMP

Boethius's "De topicis differentiis"

Boethius's "In Ciceronis Topica" 


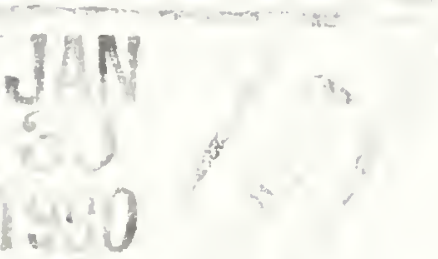

Copright (C) 1989 by Cornell University

All rights reserved. Except for brief quotations in a review, this book, or parts thereof, must not be reproduced in any form without permission in writing from the publisher. For information, address Cornell University Press, 124 Roberts Place, Ithaca, New York 14850.

First published 1989 by Cornell University Press.

The first three essays in this volume originally appeared in Boethius's "De topicis differentiiis" (Cornell University Press, 1978), copyright (C) 1978 by Eleonore Stump and used by permission of Cornell University Press. Information about the previous publication of the other essays is given in a note on the first page of each.

International Standard Book Number 0-8014-2036-9 Library of Congress Catalog Card Number 88-30348

Printed in the United States of America

Librarians: Library of Congress cataloging information appears on the last page of the book.

The paper in this book is acid-free and meets the guidelines for permanence and durability of the Committee on Production Guidelines for Book Longevity of the Council on Library Resources. 
For Norman

לכל זמן ועת לכל חפץ

תחת השמים זמי לעת

את הכל עשה יפה בעתו

Ecclesiastes 3:1,11 
Digitized by the Internet Archive in 2019 with funding from The Arcadia Fund 